\title{
Evaluation of the Biological Properties and the Enzymatic Stability of Glycosylated Luteinizing Hormone-Releasing Hormone Analogs
}

\author{
Shayli Varasteh Moradi, ${ }^{1}$ Pegah Varamini, ${ }^{1}$ and Istvan Toth ${ }^{1,2,3}$
}

Received 12 March 2015; accepted 6 April 2015; published online 9 May 2015

\begin{abstract}
The enzymatic stability, antitumor activity, and gonadotropin stimulatory effects of glycosylated luteinizing hormone-releasing hormone (LHRH) analogs were investigated in this study. Conjugation of carbohydrate units, including lactose (Lac), glucose (GS), and galactose (Gal) to LHRH peptide protected the peptide from proteolytic degradation and increased the peptides' half-lives in human plasma, rat kidney membrane enzymes, and liver homogenate markedly. Among all seven modified analogs, compound $1\left(\mathrm{Lac}-\left[\mathrm{Q}^{1}\right]\left[\mathrm{w}^{6}\right] \mathrm{LHRH}\right)$ and compound $6\left(\mathrm{GS}^{4}-\left[\mathrm{w}^{6}\right] \mathrm{LHRH}\right)$ were stable in human plasma during $4 \mathrm{~h}$ of experiment. The half-lives of compounds 1 and 6 improved significantly in kidney membrane enzymes (from $3 \mathrm{~min}$ for LHRH to 68 and $103 \mathrm{~min}$, respectively). The major cleavage sites for most of the glycosylated compounds were found to be at $\operatorname{Trp}^{3}-\operatorname{Ser}^{4}$ and $\operatorname{Ser}^{4}-\mathrm{Tyr}^{5}$ in compounds 1-5. Compound 6 was hydrolyzed at $\mathrm{Ser}^{4}-\mathrm{Tyr}^{5}$ and the sugar conjugation site. The antiproliferative activity of the glycopeptides was evaluated on LHRH receptor-positive prostate cancer cells. The glycosylated LHRH derivatives had a significant growth inhibitory effect on the LNCaP cells after a 48-h treatment. It was demonstrated that compound 1 significantly increased the release of luteinizing hormone (LH) at 5 and $10 \mathrm{nM}$ concentrations and compound $5\left(\mathrm{GS}-\left[\mathrm{Q}^{1}\right] \mathrm{LHRH}\right)$ stimulated the release of follicle-stimulating hormone (FSH) at $5 \mathrm{nM}$ concentration in dispersed rat pituitary cells $(p<0.05)$. In our studies, compound 1-bearing lactose and D-Trp was the most stable and active and is a promising candidate for future preclinical investigations in terms of in vitro biological activity and metabolic stability.
\end{abstract}

KEY WORDS: antiproliferative activity; carbohydrate conjugation; LH and FSH release; LHRH; peptide.

\section{INTRODUCTION}

Luteinizing hormone-releasing hormone (LHRH) is a hypothalamic decapeptide (pGlu-His-Trp-Ser-Tyr-Gly-LeuArg-Pro-Gly- $\mathrm{NH}_{2}$ ) with a regulatory function in the reproductive system. The secretion of this hormone from the hypothalamus stimulates its cognate receptor in the pituitary gland to produce gonadotropins including luteinizing hormone ( $\mathrm{LH})$ and follicle-stimulating hormone (FSH). Subsequently, the release of gonadotropins regulates the secretion of sex steroids in both males and females (1). A substantial number of LHRH derivatives have been developed and are administered parenterally for the treatment of various hormone-dependent diseases such as breast cancer, prostate cancer, endometriosis, infertility, and precocious puberty (2,

Electronic supplementary material The online version of this article (doi:10.1208/s12248-015-9769-x) contains supplementary material, which is available to authorized users.

${ }^{1}$ School of Chemistry and Molecular Biosciences, The University of Queensland, St. Lucia, Queensland 4072, Australia.

${ }^{2}$ School of Pharmacy, The University of Queensland, St. Lucia, Woolloongabba, Queensland 4102, Australia.

${ }^{3}$ To whom correspondence should be addressed. (e-mail: i.toth@uq.edu.au)
3). There is no oral analog of LHRH in the clinic due to its poor pharmacokinetic profiles and low oral bioavailability. The rapid clearance of peptides from the human body is one of the main issues in the development of therapeutic compounds. They have very low stability in digestive enzymes in the physiological environments. Therefore, in order to develop an orally active LHRH derivative, the stability of the peptide should be improved. Several strategies have been explored to reduce the enzymatic cleavage of peptide in physiological media. Conjugation of peptides with carbohydrate moieties has been shown to be a useful approach in improving stability and permeability of the modified analogs through biological membranes (4-6). Furthermore, a number of studies demonstrated that the efficacy of the sugarmodified peptides is preserved in different animal models (7-9).

To develop a potent drug, it is necessary to fully characterize the designed compounds for biological and physicochemical properties at the early stage of the discovery process. The promising drug candidate selected from preliminary characterization should possess desirable characteristics such as high potency, long half-life, and an appropriate physicochemical profile. Understanding the metabolic pathway of the target peptide is an important factor in evaluating the therapeutic potential of the peptide drug candidates (10). The blood, liver, and kidney are the main compartments of 
enzymatic digestion of peptides resulting in a reduction in the peptide's half-life (11). It has been reported that LHRH is metabolized by proteolytic enzymes within a short period of time post administration (12). The main cleavage sites of this peptide are $\mathrm{Trp}^{3}-\mathrm{Ser}^{4}$ and $\mathrm{Tyr}^{5}-\mathrm{Gly}^{6}$ amide bonds $(12,13)$. Typically, substitution of Gly at position 6 with a D-amino acid in LHRH increases its metabolic stability and the binding affinity to LHRH receptor $(14,15)$. Triptorelin is one of the LHRH super agonists bearing D-Trp ${ }^{6}$ and it is more stable to enzymatic degradation. Triptorelin is administered parenterally for the treatment of prostate cancer and hormone- dependent diseases (16).

It has been shown that LHRH analogs do not only suppress the pituitary-gonadal axis but also exert a direct growth inhibitory effect on the tumor growth (17). LHRH receptors are overexpressed in malignant tumors such as prostate, breast, and ovarian cancers, and they can mediate the antitumor activity of LHRH derivatives (18, 19). Various studies showed that LHRH analogs induce a significant decrease in the growth rate of the cancer cells, e.g., prostate cancer cell lines such as LNCaP and DU145 (20-22). LNCaP cells are androgen-dependent and are derived from a lymph node metastasis of prostatic carcinoma with a high level of LHRH receptor expression (20). PC3 and DU145 cells are androgen-independent and are derived from bone and brain metastasis of prostate cancer, respectively $(20,22)$. Medium-to-high affinity binding sites were also reported for LHRH agonists in LHRH receptor-positive prostate cancer cells (23). The agonists exhibited their antiproliferative effect in a doseand time-dependent manner (24). LHRH agonists and antagonists were shown to reduce the enzymatic activity of the plasminogen activator system in prostate cancer cells leading to a decrease in the migration and invasiveness of cancer cells (25). The mechanism of their growth inhibitory effects is through a different signaling transduction pathway from that in the pituitary cells $(25,26)$.

Treatment of cultured pituitary cells with LHRH agonists has been shown to alter the secretion level of $\mathrm{LH}$ and FSH from gonadotrophs. This occurs when the agonist binds to the receptor and the hormone-receptor complex is internalized $(27,28)$. The long-time exposure of LHRH receptors to the high concentrations of LHRH agonists resulted in receptor desensitization and the lower doses of the agonists increased the number of LHRH receptors followed by stimulation of LH release $(29,30)$.

In the present study, we designed LHRH derivatives by replacement of Gly residue with D-Trp and attachment of a glycosyl unit to either N-terminus or middle sequence of the peptide. The enzymatic stability of the designed compounds (1-6) was then evaluated in human plasma and rat tissue homogenates. The metabolites produced by the digestive activity of kidney membrane enzymes were characterized, followed by the examination of the degradation profile of the analogs. The direct antiproliferative potency of glycosylated LHRH analogs was examined in prostate cancer cells including LNCaP, DU 145, and PC3. We also investigated the stimulatory activity of the selected glycosylated LHRH derivatives (compounds 1, 2, 5, and 6) at low concentrations to release LH and FSH in the cultured pituitary cells.

\section{MATERIALS AND METHODS}

\section{General}

High-performance liquid chromatography (HPLC) grade acetonitrile (MeCN) was purchased from Labscan (Bangkok, Thailand) and trifluoroacetic acid (TFA) was obtained from Merck Biosciences (Kilsyth, VIC, Australia). Reversedphase HPLC (RP-HPLC) was performed using Shimadzu Instrumentation (Kyoto, Japan) (LabSolutions software, SIL-20AC HT auto-sampler, LC-20AB pump, SPD-M10A detector, DGU-20A5 degasser). The analysis was achieved using a linear $0-100$ or $20-60 \%$ gradient of solvent B (solvent A, $0.1 \%$ TFA in $\mathrm{H}_{2} \mathrm{O}$; solvent $\mathrm{B}, 90 \%$ ACN: $\mathrm{H}_{2} \mathrm{O}: 0.1 \%$ TFA) for $30 \mathrm{~min}$ with a $1-\mathrm{mL} / \mathrm{min}$ flow rate and detection at $214 \mathrm{~nm}$. The crude peptides were then purified by preparative HPLC with a linear 20-45\% gradient of solvent B to $\geq 95 \%$ purity. Analytical separations were performed using a C8 column (Vydac 208TP5205; 5: $\mathrm{m}, 2.1 \times 50 \mathrm{~mm}^{2}$, Columbia, MD, USA) or a C18 column (Vydac 218TP5405; 5: m, 4.6 $\times 50 \mathrm{~mm}^{2}$, Columbia, MD, USA). Electrospray ionization mass spectrometry was performed on a Perkin-Elmer Sciex API 3000 operating in positive ion mode. A Varian Cary 50 Bio UV-vis spectrophotometer was used for absorbance measurement.

LNCaP (androgen-sensitive prostate adenocarcinoma) and DU145 (androgen-independent human carcinoma) human cell lines were used and were kindly provided by Professor Judith Clements at the Translational Research Institute, Queensland University of Technology. PC3 (steroid hormone-independent prostate adenocarcinoma) cells were kindly donated by Professor Rodney Minchin, School of Biomedical Sciences, The University of Queensland; Dulbecco's modified Eagle's medium (DMEM); penicillin/streptomycin; fetal bovine serum (FBS); and phosphate-buffered saline (PBS) were obtained from Life Technologies Australia (Mulgrave, VIC, Australia). Tris (hydroxymethyl) aminomethane hydrochloride (Tris- $\mathrm{HCl}$ ) was purchased from ICN Biomedical Inc. (OH, USA). $\mathrm{MgCl}_{2} \cdot 6 \mathrm{H}_{2} \mathrm{O}$ was obtained from Sigma-Aldrich (Castle Hill, NSW, Australia).

\section{Peptide Synthesis}

All LHRH analogs were synthesized using Fmoc solid phase peptide synthesis (SPPS) based on the previously published methods (Fig. 1) (31).

\section{In Vitro Metabolic Stability Assay}

\section{Human Plasma Stability Assay}

The test was performed on fresh human plasma of consenting and healthy volunteers (ethics approval number: 2006000950). Plasma was separated from red blood cells by a 15 -min centrifugation at $1500 \times g$ and diluted to $80 \%$ by adding $1 \times$ PBS. The compound's solution was prepared in PBS at $600 \mu \mathrm{M}$. Plasma $(300 \mu \mathrm{L})$ was spiked with the peptide solutions at $1: 1$ ratio (incubated at $37^{\circ} \mathrm{C}$ ). During the time course of the experiment $(4 \mathrm{~h})$, samples were collected and 


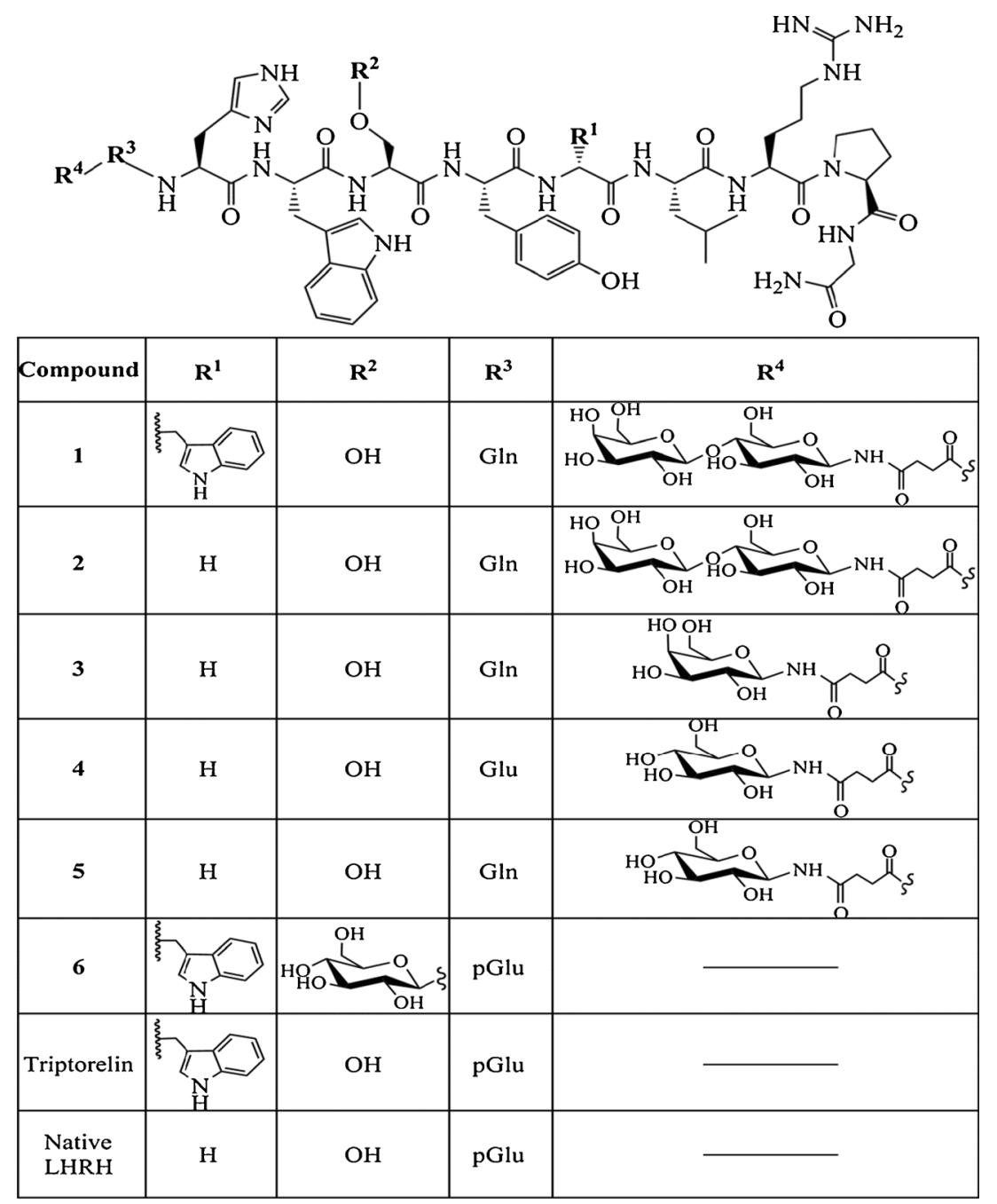

Fig. 1. Chemical structure of the glycosylated LHRH analogs

mixed with acetonitrile for quenching the reaction. Finally, the protein mixture was centrifuged at $7400 \times g$ for $10 \mathrm{~min}$ and the supernatant was separated from the mixture and analyzed by RP-HPLC. A calibration curve of each compound was plotted (peak area of serial dilutions versus the concentrations) to calculate the concentration of the peptide in the sample's solutions.

\section{Rat Tissue Preparation}

Male Sprague-Dawley rats $(180 \pm 20 \mathrm{~g}$ were obtained from the Animal Resource Centre (ARC). All experimental procedures were approved by The University of Queensland Animal Ethics Committee (AEC\#SCMB/005/11/ARC) and performed according to NHMRC animal handling guidelines. Animals were euthanized and their kidneys and livers were removed to prepare tissue homogenates. The rat liver homogenate, S9 (containing both cytosolic and microsomal enzymes) was prepared according to the previously published methods (32, $33)$. Briefly, the fresh rat liver was weighed and washed with icecold $0.9 \%$ sodium chloride solution. The tissue was cut into small pieces followed by mixing with $3 \mathrm{~mL}$ of $20 \mathrm{mM}$ Tris- $\mathrm{HCl}$ buffer ( $\mathrm{pH} 7.4$ ), containing $0.25 \mathrm{M}$ sucrose per $1 \mathrm{~g}$ of tissue. The samples were then homogenized with the ice-cold buffer in a Teflon homogenizer using 4-6 pestle strokes. The homogenate was centrifuged at $3000 \times g$ for $15 \mathrm{~min}$ at $4^{\circ} \mathrm{C}$ and the supernatant was decanted. The total protein count was determined using Bradford assay and the protein concentration was adjusted to $2.5 \mathrm{mg} / \mathrm{mL}$. The kidney membrane homogenate was prepared according to the procedure described by Vergote et al. with minor modifications (10). In brief, rat kidneys were washed with ice-cold $0.9 \%$ sodium chloride and transferred into the Tris- $\mathrm{HCl}$ buffer ( $2 \mathrm{mM}$ containing $10 \mathrm{mM}$ mannitol, $\mathrm{pH}$ 7.3). After cutting into pieces, the tissue was homogenized by a Teflon homogenizer followed by centrifugation of the homogenate suspended in ice-cold $10 \mathrm{mM} \mathrm{MgCl} 2 \cdot 6 \mathrm{H}_{2} \mathrm{O}$ and $2 \mathrm{mM}$ Tris- $\mathrm{HCl}$ buffer $\left(1500 \times g, 15 \mathrm{~min}\right.$ at $\left.5^{\circ} \mathrm{C}\right)$. The supernatant was removed and the pellet was re-suspended in the ice-cold buffer and centrifuged at $15,000 \times g$ for $15 \mathrm{~min}$ at $5^{\circ} \mathrm{C}$. The supernatant was discarded again and the pellet was re-suspended in the buffer and centrifuged at $2200 \times \mathrm{g}$ for $15 \mathrm{~min}$ at $5^{\circ} \mathrm{C}$. After discarding the supernatant, the suspended pellet was again centrifuged at $15,000 \times \mathrm{g}$ for $15 \mathrm{~min}$ at $5^{\circ} \mathrm{C}$. The supernatant was decanted and the final pellet was resuspended in the same Tris- $\mathrm{HCl}$ buffer mix. The total protein content of the suspended pellet was measured by Bradford assay and adjusted to $2.5 \mathrm{mg} / \mathrm{mL}$. 


\section{Incubation of the Peptide Analogs with Homogenates}

The homogenates were added $(100 \mu \mathrm{L})$ into each well of the 96-well plates. Prior to the start of the experiment, the homogenates were pre-warmed for $15 \mathrm{~min}$ at $37^{\circ} \mathrm{C}$. $\mathrm{LHRH}$ compounds were dissolved in PBS and added to the homogenates to give a final concentration of $100 \mu \mathrm{M}$. The reaction was initiated by incubating the plates at $37^{\circ} \mathrm{C}$ and shaking at $50 \mathrm{rpm}$ (Thermo Scientific MaxQ 4000 Benchtop shaker, USA). Samples of $50 \mu \mathrm{L}$ were collected from each well at pre-determined time intervals $(0,5,10,15,20,30,40$, $60,90,120,180$, and $240 \mathrm{~min}$ ) and added to the $50 \mu \mathrm{L}$ of $80 \%$ acetonitrile containing $0.1 \%$ formic acid to stop the enzymatic activity. Samples were finally centrifuged at $3000 \times g$ for $15 \mathrm{~min}$; the supernatants were collected and analyzed using HPLC on a C8 column.

\section{Identification of Metabolites}

The metabolites formed by the degradation of the compounds in the kidney membrane homogenate and human plasma were characterized using HPLC and ESI-mass spectrometry. The peaks from the HPLC were collected and the corresponding mass was identified using mass spectrometry (PerkinElmer-Sciex API3000).

\section{In Vitro Cell Proliferation Assay}

LNCaP and DU145 cell lines were grown in $75 \mathrm{~cm}^{2}$ culture flasks containing RPMI-1640 medium supplemented with $10 \%$ fetal bovine serum (FBS) and 1\% non-essential amino acids in a humidified atmosphere of $5 \% \mathrm{CO}_{2}$. Dulbecco's modified Eagle's medium (DMEM) was used to grow the PC3 cell line. The cell media were changed every 2 days.

The cell proliferation was evaluated by assessing the mitochondrial reduction of MTT using the established procedure (34). Tumor cells including LNCaP, DU145, and PC3 were seeded at the density of $2.0 \times 10^{4}$ cells/well and allowed to attach for $4 \mathrm{~h}$. LHRH compounds were added to the plates at different concentrations $(10,50,100$, and $200 \mu \mathrm{M})$ in triplicate. Cells were incubated for 48, 72, and $96 \mathrm{~h}$ at $37^{\circ} \mathrm{C}$. Fresh compound solution was added to the cells every other day. After the end of the treatment, $10 \mu \mathrm{L}$ MTT $(5 \mathrm{mg} / \mathrm{mL})$ was added to each well. Plates were incubated for a further $4 \mathrm{~h}$. The medium was aspirated and $200 \mu \mathrm{L}$ acidified isopropanol $(0.1 \mathrm{~N} \mathrm{HCl})$ was added to the wells to dissolve formazan crystals. The absorption of each well was measured using a Spectramax 250 microplate reader at the wavelength of $570 \mathrm{~nm}$. The percentage of cell viability for each compound was calculated by comparing the absorbance of PBS added samples (as a negative control). Sodium dodecyl sulfate (SDS) was used as a positive control. Each experiment was repeated twice.

\section{Isolation of Peripheral Blood Mononuclear Cells (PBMCs)}

Assay was performed with the approval from the University of Queensland Ethics Committee (ethical approval number: 2009000661). A blood sample (4 mL) was collected from a healthy adult volunteer and diluted with an equal volume of RPMI. Diluted cell suspension was layered over $4 \mathrm{~mL}$ Ficoll and centrifuged at $400 \times \mathrm{g}$ for $30 \mathrm{~min}$. The white cell interface including mononuclear cells was aspirated and washed three times with RPMI 1640. Cells were re-suspended in $10 \%$ FBS:RPMI and seeded in a 96-well flat bottom plate (TPP) at the density of $1 \times 10^{6}$ cells $/ \mathrm{mL}$. Cells were then activated by adding $10 \mu \mathrm{g} / \mathrm{mL}$ of phytohemagglutinin and incubated at $37^{\circ} \mathrm{C}$ in a $5 \% \mathrm{CO}_{2}$ atmosphere. After 1-h incubation, $10 \mu \mathrm{L}$ of $\mathrm{LHRH}$ derivative was added to each well at 50 and $200 \mu \mathrm{M}$. An MTT assay was performed after 48-h incubation using the same method as described for the cell proliferation assay.

\section{LH and FSH Release Assays}

\section{Rat Pituitary Cell Preparation}

Pituitary cell dispersion was performed as described elsewhere with some modifications (35). Briefly, anterior pituitaries were removed immediately after euthanizing rats by $\mathrm{CO}_{2}$ inhalation and rinsed with Hanks' balanced salt solution (HBSS) containing $25 \mathrm{mM} \mathrm{N}$-2-hydroxyethylpiperazine- $\mathrm{N}$-2ethane sulfonic acid (HEPES) buffer ( $\mathrm{pH}$ 7.2). Tissues were minced with a razor blade into small pieces. The buffer was removed and replaced by a collagenase enzyme solution $(1 \mathrm{mg} /$ $\mathrm{mL}$ dissolved in $1 \%$ bovine serum albumin (BSA)/HBSS). The pituitary fragments were incubated with the enzyme for $1 \mathrm{~h}$ at $37^{\circ} \mathrm{C}$ to become dissociated. After a gentle trituration, cells were passed through a cell strainer (Costar) to remove clumps and centrifuged at $400 \times g$ for $10 \mathrm{~min}$. The supernatant was decanted and the cells were suspended in DMEM media supplemented with $10 \%$ FBS (growth media). Afterwards, cells were plated in 96-well plates at the density of 30,000 cells/well and incubated for $72 \mathrm{~h}$ at $37^{\circ} \mathrm{C}$.

\section{LH and FSH Measurement}

Plated pituitary cells were spun down at $1200 \times g$ for $10 \mathrm{~min}$. Before the addition of LHRH compounds, pituitary cells were washed and replaced by challenging media containing DMEM with $0.1 \%$ BSA. Plates were then incubated with $10 \mu \mathrm{L}$ test solutions at $37^{\circ} \mathrm{C}$ for $2 \mathrm{~h}$. Compounds were used at 1, 10, and $50 \mathrm{nM}$ for the $\mathrm{LH}$ release assay and at $0.5,5$, and $10 \mathrm{nM}$ (concentrations were chosen based on some preliminary experiments) for the FSH release experiment. The level of $\mathrm{LH}$ and FSH was quantified with the commercial ELISA kit (USCN Life Science Inc., Wuhan, China) according to the manufacturer's instructions.

\section{RESULTS}

\section{Designed LHRH Analogs}

Peptide derivatives were synthesized and purified to 9599\% purity according to previously published methods (6, 31). The pure peptides were used for the biological evaluations. Figure 1 shows the chemical structure of the glycosylated LHRH analogs. In all compounds, the carbohydrate units were attached to the $\mathrm{N}$-terminus of the peptide via a succinamic acid linker except for compound 6 in which the 
glucose unit was coupled to the serine residue at position 4 through O-glycosylation.

\section{In Vitro Metabolic Stability of LHRH Derivatives}

To assess the metabolic stability of LHRH derivatives in human plasma, compounds were incubated with plasma for $4 \mathrm{~h}$ and the half-life of each LHRH derivative was calculated after quantifying the collected samples using HPLC. The results showed that compounds 1 (bearing Lac at N-terminus and $\mathrm{D}-\operatorname{Trp}^{6}$ ) and 6 (bearing $\mathrm{GS}^{4}$ and $\mathrm{D}$-Trp ${ }^{6}$ ) were stable during the time course of the experiment. A significant increase was also observed in the plasma half-lives of the compounds 2-5 compared to the native peptide (from $\mathrm{t}_{1 / 2}=6 \mathrm{~min}$ to more than $120 \mathrm{~min}$ ).

The enzymatic stability of the glycosylated conjugates of LHRH was also studied in rat liver and kidney membrane homogenates at $\mathrm{pH} 7.3$ (Table I). The half-lives of compounds 1 and 2 in liver homogenate were 117 and $42 \mathrm{~min}$, respectively, which were enhanced significantly compared to the parent peptide $\left(t_{1 / 2}=5 \mathrm{~min}\right)$. The metabolic stability of compounds 1 and 2 was also improved between 7 - and 22-fold in kidney membrane homogenate. Compound 6 was stable in liver homogenate for $4 \mathrm{~h}$ and showed the highest half-life in kidney membrane homogenate $\left(\mathrm{t}_{1 / 2}=103 \mathrm{~min}\right)$ compared to the other derivatives. The shortest half-life in both homogenates was obtained for those compounds that had glucose and galactose units in the N-terminal of their structures (compounds 3-5). It was demonstrated that the glycosylated LHRH derivatives were more rapidly hydrolyzed in the kidney membrane homogenates than the liver homogenates. Among the tested LHRH derivatives, compound 1 and compound 6 were the most stable analogs, whereas compound 3 had the least metabolic stability in all three matrices.

\section{Characterization of the Metabolites}

The metabolites generated by the enzymatic digestion of LHRH analogs were identified in kidney membrane and human plasma stability experiments. No degraded products were found in the samples incubated with plasma; however, several metabolites were identified upon the incubation of the analogs in the kidney membrane homogenate. All fragments were eluted from HPLC earlier than the native peptide in the chromatographic separation using a gradient solvent system. The analysis of the fragments illustrated indicated that the peptide bonds $\operatorname{Trp}^{3}-\operatorname{Ser}^{4}$ and $\operatorname{Ser}^{4}-\mathrm{Tyr}^{5}$ were the most susceptible positions in compounds $1-5$, which were cleaved after 10- and 15-min incubation with the homogenate, respectively. Moreover, the cleavage of the $\mathrm{Tyr}^{5}-\mathrm{Gly}^{6}$ bond was detected in compounds $1-5$. The lactose unit was cleaved from the LHRH peptide in compound 1 after $40 \mathrm{~min}$, while the cleavage between the glucose residue and the peptide in compounds 4 and 5 was observed after $20 \mathrm{~min}$.

Compound 6 was stable in the kidney homogenate, and no metabolites were detected in the samples until $180 \mathrm{~min}$. After $180 \mathrm{~min}$, a metabolite was detected by the cleavage of the glucose from the peptide. Another degradation site was found for compound 6 after $240 \mathrm{~min}$ at $\mathrm{Ser}^{4}-\mathrm{Tyr}^{5}$.

\section{In Vitro Antiproliferative Study}

The growth inhibitory effect of glycosylated conjugates of LHRH was investigated in three LHRH receptor-positive prostate cancer cell lines (LNCaP, DU145, and PC3). Cells were treated with the different doses of LHRH compounds and their effects on cell growth were assessed during four consecutive days. The cell growth in LNCaP cells decreased between 35 and $53 \%$ after 48 -h treatment with compounds 16 (at 100 and $200 \mu \mathrm{M}$ concentrations). Similar inhibitory effects on cell growth were observed after the treatment of LNCaP cells for 72 and $96 \mathrm{~h}$ (30 to $55 \%$ growth reduction) (Fig. 2a, S1-A). It was shown that LHRH compounds induced the same or even higher levels of growth inhibition in LNCaP cells compared to triptorelin at $200 \mu \mathrm{M}$ concentration. This effect was in a concentration-dependent manner.

The growth rate of DU145 cells was not changed significantly when cells were treated with glycosylated LHRH derivatives for $48 \mathrm{~h}$. However, the cell growth was inhibited evidently ( $40 \%$ reduction) after $72 \mathrm{~h}$ treatment of the cells with the compounds at 50,100, and $200 \mu \mathrm{M}$ concentrations (Fig. S1-B). Compounds 1, 2, 4, and 6 reduced the viability of DU145 cells to less than $50 \%$ after a 4-day treatment (Fig. 2b). Similar to the LNCaP cell line, the cell growth inhibitory effect of the sugar-modified compounds was concentration-dependent in DU145 cells.

No significant change was observed in the growth of PC3 cells after 48 and $72 \mathrm{~h}$ of treatments (Fig. S1-C). However, the

Table I. Half-Lives of Glycosylated LHRH Derivatives in Human Plasma and Tissue Homogenates

\begin{tabular}{|c|c|c|c|c|}
\hline \multirow[b]{2}{*}{ Compound number } & \multirow[b]{2}{*}{ Peptide derivatives } & \multicolumn{3}{|l|}{ Half-life (min) } \\
\hline & & Rat liver homogenate & Rat kidney membranes & Human plasma \\
\hline- & [pGlu]ㄴHRH (native) & 5 & 3 & 6 \\
\hline 1 & Lac- $\left[\mathrm{Q}^{1}\right]\left[\mathrm{w}^{6}\right] \mathrm{LHRH}$ & 117 & 68 & Stable $^{a}$ \\
\hline 2 & Lac- $\left[\mathrm{Q}^{1}\right] \mathrm{LHRH}$ & 42 & 22 & 187 \\
\hline 3 & Gal-[Q $\left.\mathrm{Q}^{1}\right] \mathrm{LHRH}$ & 17 & 8 & 124 \\
\hline 4 & GS- $\left[E^{1}\right]$ LHRH & 17 & 8 & 138 \\
\hline 5 & GS- $\left[\mathrm{Q}^{1}\right] \mathrm{LHRH}$ & 22 & 8 & 146 \\
\hline 6 & $\mathrm{GS}^{4}-\left[\mathrm{w}^{6}\right] \mathrm{LHRH}$ & Stable $^{a}$ & 103 & Stable $^{a}$ \\
\hline
\end{tabular}

All metabolic stability assays were performed in triplicate in two independent repetitions. The half-life values are reported as the mean of repeated experiments

LHRH luteinizing hormone-releasing hormone, Lac lactose, Gal galactose, GS glucose

${ }^{a}$ Compounds were stable during the time course of the experiment $(4 \mathrm{~h})$ 

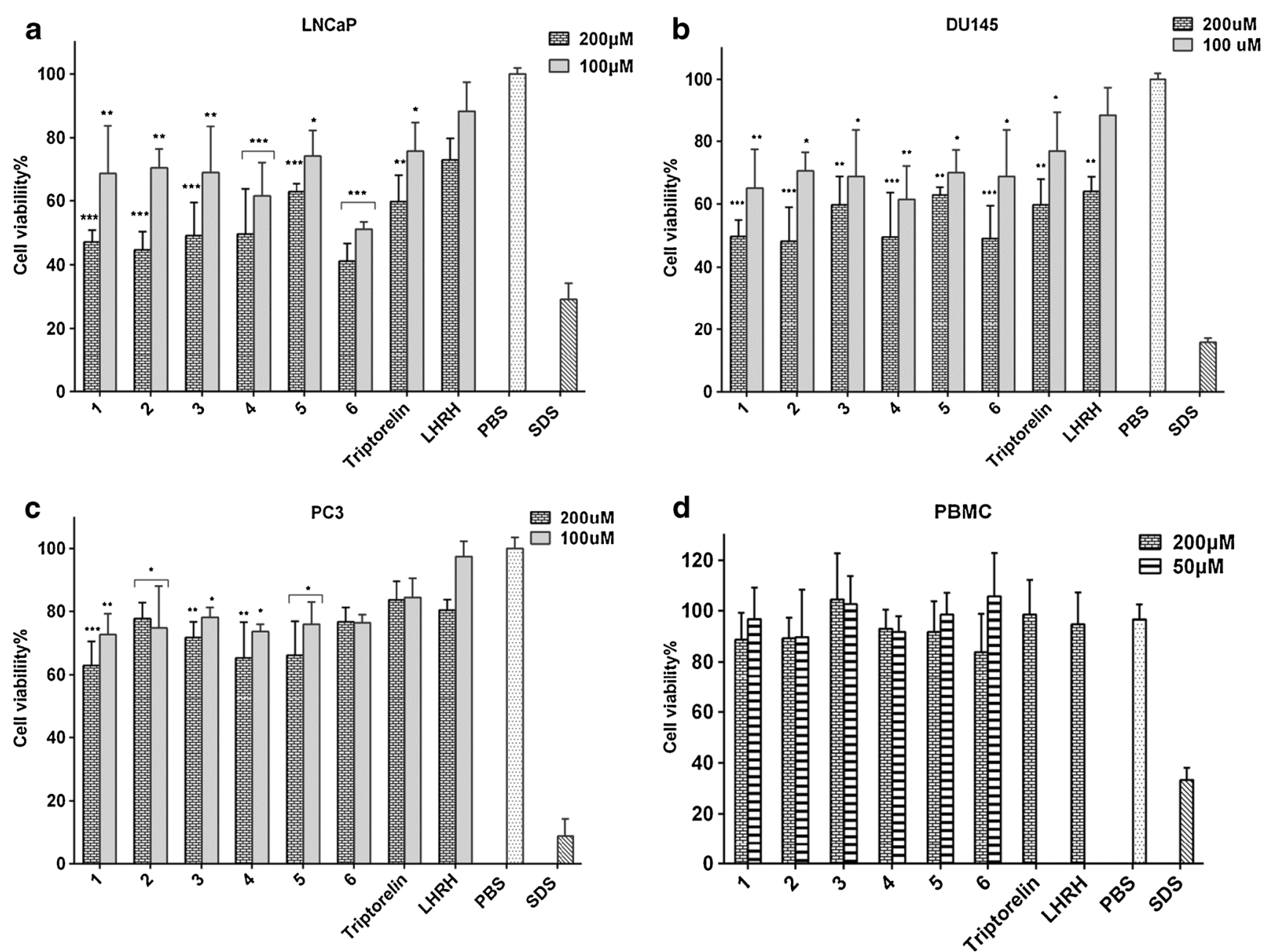

Fig 2. Antiproliferative effects of glycosylated LHRH analogs in cancer cell lines. a LNCaP, b DU145, and $\mathbf{c}$ PC3. Cancer cells were treated with LHRH compounds for 48, 72, and $96 \mathrm{~h}$ at 10, 50,100, and $200 \mu \mathrm{M}$. In this figure, the growth inhibitory effect of compounds is shown after 96-h treatment at 100 and $200 \mu \mathrm{M}$. All other relevant graphs are presented in supplementary information. d In normal PBMCs, the growth inhibitory effects of LHRH derivatives at 50 and $200 \mu \mathrm{M}$ was determined following 48-h incubation with cells. Each column represents the mean \pm SD of the data obtained from experiments performed in triplicate. Statistical analysis was performed using a one-way ANOVA followed by the Dunnett's post hoc test and compared to PBS group $\left({ }^{*} p<0.05, * * p<0.01, * * * p<0.01\right)$

incubation of PC3 cells with LHRH derivatives elicited up to $37 \%$ growth inhibition after a 4-day incubation at 100 and $200 \mu \mathrm{M}$ concentrations (Fig. 2c). All tested compounds showed a superior inhibitory effect on the growth of LNCaP and DU145 cell lines than PC3 cells. LNCaP cells were kept for an additional 5 days without any treatment with compounds. The cells resumed growth after 5 days and their viability reached the level of the negative control wells.

\section{Cell Toxicity Against Non-cancerous Peripheral Blood Mononuclear Cells (PBMCs)}

The toxicity of compounds 1-6 was evaluated in PBMCs isolated from the whole blood. None of the compounds showed any toxic effect on these cells at 50 and $200 \mu \mathrm{M}$ concentrations (Fig. 2d).

\section{In vitro LH and FSH Release}

The level of released LH and FSH was measured after 2-h incubation of compounds $1,2,5$, and 6 (lead compounds selected based on our preliminary results) with the cultured pituitary cells. Compound 1 at $10 \mathrm{nM}$ concentration stimulated the release of LH significantly from $47 \mathrm{ng} / \mathrm{mL}$ in the negative control samples to $117 \mathrm{ng} / \mathrm{mL}$ (Fig. 3). The concentration of $1 \mathrm{nM}$ caused a 2-fold increase in LH release, although it was not statistically significant. However, a higher concentration of the compound 1 ( $50 \mathrm{nM})$ did not affect the LH level. Compound 6 inhibited the LH release significantly at $50 \mathrm{nM}$. Compounds 2 and 5 did not show significant effects in altering the release of LH at any concentration (Fig. 3). Compound 5 had a significant effect in increasing the secretion of FSH at $5 \mathrm{nM}$. The FSH level was not significantly altered when the cells were treated by compounds 1 and 2 at any concentration.

\section{DISCUSSION}

The therapeutic benefits of LHRH derivatives have been proven in the treatment of hormone-dependent diseases (36, 37). However, all agonists and antagonists of LHRH are characterized by poor pharmacokinetic properties when they are orally administered. The development of orally active 

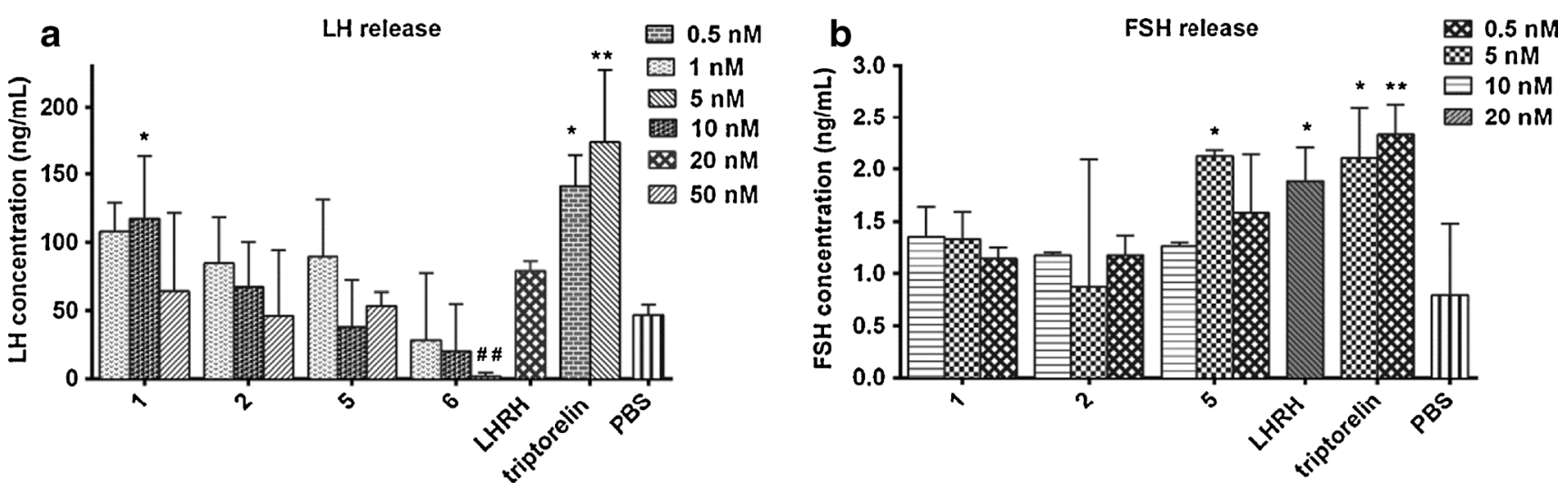

Fig. 3. Effect of glycosylated LHRH derivatives on the release of a LH and $\mathbf{b}$ FSH in rat pituitary cells. Statistical analysis was performed using a one-way ANOVA followed by the Dunnett's post hoc test. ${ }^{\# \#} p<0.05$, decrease in the LH level when compared to the PBS group $\left({ }^{*} p<0.05\right.$, $* * p<0.01$, increase in the LH level when compared to the PBS group)

peptide drugs has been one of the major goals in the pharmaceutical industry. Enzymatic digestion is one of the main limiting factors in the oral delivery of peptides leading to poor absorption from the gastrointestinal tract into the systemic circulation. Several approaches have been employed to overcome these challenges. We applied the glycosylation approach and amino acid substitution with D-isoform to overcome the poor oral bioavailability of native LHRH peptide. We previously reported the enhanced stability of the LHRH glycosylated derivatives in the Caco-2 cell homogenates (31). Caco-2 cells are derived from human colon adenocarcinoma, and they express the typical enzymes of intestinal cells such as peptidases in high levels. Therefore, they are applied as a useful model for drug metabolism studies (38). In addition to intestinal enzymes, the liver and kidney are the two main organs responsible for metabolizing hydrophilic peptides using different types of proteases. In this study, the metabolic stability of the designed LHRH analogs was evaluated in rat liver and kidney membrane homogenates. The results indicated that the metabolic stability of all glycosylated analogs improved significantly in the liver homogenate compared to the native peptide and the compounds bearing glucose and lactose with D-Trp ${ }^{6}$ amino acid in the sequence (compounds 1 and 6) were the most resistant analogs against enzymatic digestion. The glycosylated LHRH compounds were shown to be less stable against metabolizing enzymes in the kidney compared to that of the liver. This was in line with the previous studies showing that the kidney plays an important role in the metabolism of LHRH derivatives $(39,40)$. The native LHRH is degraded rapidly in blood and has a short half-life of 3-4 min (36). We showed that compounds 1 and 6 remained intact in the human plasma during the 4-h incubation. The half-lives of compounds 2-5 increased 20- to 30-fold compared to the LHRH peptide. Overall, it was found that the introduction of a D-amino acid and a lactose unit to the structure of LHRH peptide had a significant impact in improving the metabolic stability of the modified analogs. Furthermore, the attachment of a glucose unit at position 4 in compound 6 was shown to be the most effective approach in the current study to protect the peptide against enzymatic degradation.

The production of major metabolites of the compounds 1-6 was examined upon incubation in the kidney membrane homogenate. Compound 6 with the glucose unit attached to the middle of the sequence showed higher metabolic stability than other derivatives. No hydrolyzed metabolites were formed until 180-min incubation with the homogenate. After $180 \mathrm{~min}$, a glucose-free fragment and after $240 \mathrm{~min}$, a hexapeptide (Tyr ${ }^{5}$-D$\mathrm{Trp}^{6}$ - $\mathrm{Leu}^{7}-\mathrm{Arg}^{8}$-Pro ${ }^{9}-\mathrm{Gly}^{10}-\mathrm{NH}_{2}$ ) was detected. It was found that the kidney endopeptidases cleaved the peptide bond at positions 3 and 4 in compounds $1-5$. This caused the formation of a hexapetide $\left(\mathrm{Tyr}^{5}-\mathrm{Gly}^{6}{ }^{6}\right.$ or D-Trp ${ }^{6}$ ]-Leu ${ }^{7}-\mathrm{Arg}^{8}$-Pro ${ }^{9}-\mathrm{Gly}^{10}$ $\mathrm{NH}_{2}$ ) and heptapeptide (Ser ${ }^{4}-\mathrm{Tyr}^{5}-\mathrm{Gly}^{6}$ [or D-Trp ${ }^{6}$ - $\mathrm{Leu}^{7}-\mathrm{Arg}^{8}$ $\mathrm{Pro}^{9}-\mathrm{Gly}^{10}-\mathrm{NH}_{2}$ ) in the homogenate. The $\mathrm{Tyr}^{5}-\mathrm{Gly}^{6}$ bond was also degraded in compounds bearing Gly at position 6 (compounds 2-5). This digestion pattern was reported for LHRH, and its analogs in other studies in which the stability of the peptide's derivatives was examined in different tissue homogenates and organs (41-43). It has been shown that metalloendopeptidase EP24.15, EP24.11, and the angiotensinconverting enzyme (ACE) are mainly responsible for digestion of the LHRH peptide. The endopeptidase E24.15 cleaves the peptide bonds at $\mathrm{Tyr}^{5}-\mathrm{Gly}^{6}$ and $\mathrm{His}^{2}-\mathrm{Trp}^{3}$ whereas ACE degrades the bond at $\operatorname{Try}^{3}-\operatorname{Ser}^{4}$ (44-46). The cleavage of the sugar entities was found to be processed in the later stage of the proteolytic reaction. It was also observed that pyroglutamyl residue (pGlu) was cleaved after the removal of the sugar entities from the N-terminus of the peptides' sequence. The cleavage of pGlu from the amino terminus of the peptides is instigated by the enzymatic activity of pyroglutamyl peptidase distributed in different mammalian tissues (47).

In addition to the suppression of gonadal steroids, a number of studies reported the direct antiproliferative activity of LHRH analogs in different tumor cell lines $(17,48,49)$. However, the mechanism of the action of LHRH analogs on tumor cells is mediated through a different signal transduction pathway from that in the anterior pituitary $(20,50)$. We tested the growth inhibitory effect of the LHRH derivatives in three prostate cancer cell lines including LNCaP, DU145, and PC3. We found that all tested peptide analogs markedly inhibited the growth of LNCaP and DU145 cells after 48- and 72-h treatment, respectively. There was no significant difference between the antiproliferative effects of compound 6 bearing a sugar unit at position 6 and the other glycosylated analogs in which the sugar entities were attached to the $\mathrm{N}$ terminus of the peptide. There are reports in the literature on 
the direct inhibitory activity of other LHRH analogs in these two cancer cell lines (22). The tested peptide analogs in this study showed no significant effect on the growth of PC3 cells during 72 -h treatment. However, there was a $22-38 \%$ decrease in the growth of these cells after 96-h incubation with the glycosylated LHRH analogs. In comparison with LNCaP and DU145 cells, the growth of PC3 cells was less affected by the LHRH compounds. It has been reported that LNCaP cells overexpress LHRH receptors with moderately high- and low-affinity binding sites for the ligand, whereas PC3 cells have only low-affinity binding sites for the ligands (20). We also showed that the glycosylated LHRH derivatives had no toxic effect on normal peripheral blood cells suggesting the selective antitumor activity of the compounds.

The stimulatory effect of glycosylated LHRH derivatives on LH and FSH release from dispersed pituitary cells was also examined in this study. The level of LH released in cultured rat pituitary cells was measured after the treatment of the cells with compounds 1,2, 5, and 6 at different concentrations. The best stimulatory effect was observed for compound 1 at 5 and $10 \mathrm{nM}$ whereas compounds 2 and 5 did not exert any significant impact on the secretion of $\mathrm{LH}$. Compound 6 reduced the secretion of LH significantly at high concentration $(50 \mathrm{nM})$ compared to the negative control. There are evidences showing that LHRH analogs could have different effects on the LH release. The higher concentrations of LHRH receptor ligands can desensitize the pituitary cells in a time- and dose-dependent manner $(29,51,52)$. It was found that compounds 1 and 6 have the potential to change the LH release from the anterior pituitary cells. Among all LHRH-glycosylated conjugates, it was demonstrated that only compound 5 induced the release of FSH effectively, although it did not stimulate the release of LH in the pituitary cells. In previous studies, it has been explained that LHRH ligands and androgens have a differential effect on the release of LH and FSH. This has been shown to be due to the independent control over $\mathrm{LH}$ and FSH secretion both in vitro and in vivo $(53,54)$.

\section{CONCLUSIONS}

In conclusion, we showed that the conjugation of carbohydrate units to LHRH enhanced its metabolic stability and protected the peptide from enzymatic digestion significantly in rat tissue homogenates and human plasma. Furthermore, the modified peptides exhibited an inhibitory effect on the growth of the prostate cancer cell, LNCaP, DU145 and to a lesser extent on PC3 cells. Compound 1 ( $\left.\mathrm{Lac}\left[\mathrm{Q}^{1}\right]\left[\mathrm{w}^{6}\right] \mathrm{LHRH}\right)$ was able to stimulate LH release from anterior pituitary cells at lower concentrations, and compound 5 increased the secretion of FSH in cultured pituitary cells. Overall, compound 1 was the most promising candidate with the desired stimulatory effect on $\mathrm{LH}$ secretion from pituitary, in vitro antitumor activity and improved metabolic stability.

\section{ACKNOWLEDGMENTS}

This work was funded by an Australian Research Council project grant (DP110100212), and Shayli Varasteh Moradi was supported by a UQ International (UQI) scholarship.

\section{REFERENCES}

1. Conn PD, Michael P, Crowley Jr M, William F. Gonadotropinreleasing hormone and its analogs. Annu Rev Med. 1994;45(1):391-405.

2. Engel JB, Schally AV. Drug insight: clinical use of agonists and antagonists of luteinizing-hormone-releasing hormone. Nat Clin Pract Endocrinol Metab. 2007;3(2):157-67.

3. Limonta P, Moretti RM, Marelli MM, Motta M. The biology of gonadotropin hormone-releasing hormone: role in the control of tumor growth and progression in humans. Front Neuroendocrinol. 2003;24(4):279-95.

4. Powell MF, Stewart T, Otvos L, Urge L, Gaeta FCA, Sette A, et al. Peptide stability in drug development. II. Effect of single amino acid substitution and glycosylation on peptide reactivity in human serum. Pharm Res. 1993;10(9):1268-73.

5. Christie MP, Simerská P, Jen FE-C, Hussein WM, Rawi MF, Hartley-Tassell LE, et al. A drug delivery strategy: binding enkephalin to asialoglycoprotein receptor by enzymatic galactosylation. PLoS ONE. 2014;9(4):e95024.

6. Moradi SV, Varamini P, Toth I. The transport and efflux of glycosylated luteinising hormone-releasing hormone analogs in Caco-2 cell model: contributions of glucose transporters and efflux systems. J Pharm Sci. 2014;103(10):3217-24.

7. Egleton R, Mitchell S, Huber J, Palian M, Polt R, Davis T. Improved blood-brain barrier penetration and enhanced analgesia of an opioid peptide by glycosylation. J Pharmacol Exp Ther. 2001;299(3):967-72.

8. Varamini P, Mansfeld FM, Blanchfield JT, Wyse BD, Smith MT, Toth I. Synthesis and biological evaluation of an orally active glycosylated endomorphin-1. J Med Chem. 2012;55(12):5859-67.

9. Yamamoto T, Nair P, Jacobsen NE, Vagner J, Kulkarni V, Davis $\mathrm{P}$, et al. Improving metabolic stability by glycosylation: bifunctional peptide derivatives that are opioid receptor agonists and neurokinin 1 receptor antagonists. J Med Chem. 2009;52(16):5164-75.

10. Vergote V, Van Dorpe S, Peremans K, Burvenich C, De Spiegeleer B. In vitro metabolic stability of obestatin: kinetics and identification of cleavage products. Peptides. 2008;29(10):1740-8.

11. Werle M, Bernkop-Schnürch A. Strategies to improve plasma half life time of peptide and protein drugs. Amino Acids. 2006;30(4):351-67.

12. Cleverly $\mathrm{K}, \mathrm{Wu}$ TJ. Is the metalloendopeptidase EC 3.4. 24.15 (EP24. 15), the enzyme that cleaves luteinizing hormonereleasing hormone (LHRH), an activating enzyme? Reproduction. 2010;139(2):319-30.

13. Péter A, Devadder S, Laus G, Tourwé D. Liquid chromatography studies on the enzymatic degradation of luteinizing hormone-releasing hormone analogs with off-line identification by mass spectrometry. J Chromatogr A. 1996;729(1):13742.

14. Brudel M, Kertscher U, Berger H, Mehlis B. Liquid chromatographic-mass spectrometric studies on the enzymatic degradation of gonadotropin-releasing hormone. J Chromatogr A. 1994;661(1):55-60.

15. Sealfon SC, Weinstein H, Millar RP. Molecular mechanisms of ligand interaction with the gonadotropin-releasing hormone receptor. Endocr Rev. 1997;18(2):180-205.

16. Bachhav YG, Kalia YN. Stability of triptorelin in the presence of dermis and epidermis. Int J Pharm. 2009;378(1):149-51.

17. Kraus S, Naor Z, Seger R. Gonadotropin-releasing hormone in apoptosis of prostate cancer cells. Cancer Lett. 2006;234(2):10923.

18. Schally AV, Nagy A. New approaches to treatment of various cancers based on cytotoxic analogs of LHRH, somatostatin and bombesin. Life Sci. 2003;72(21):2305-20.

19. Mezo G, Manea M, Szabo I, Vincze B, Kovacs M. New derivatives of $\mathrm{GnRH}$ as potential anticancer therapeutic agents. Curr Med Chem. 2008;15(23):2366-79.

20. Ravenna L, Salvatori L, Morrone S, Lubrano C, Cardillo M, Sciarra F, et al. Effects of triptorelin, a gonadotropin-releasing hormone agonist, on the human prostatic cell lines PC3 and LNCaP. J Androl. 2000;21(4):549-57. 
21. Morgan K, Stewart AJ, Miller N, Mullen P, Muir M, Dodds M, et al. Gonadotropin-releasing hormone receptor levels and cell context affect tumor cell responses to agonist in vitro and in vivo. Cancer Res. 2008;68(15):6331-40.

22. Dondi D, Limonta P, Moretti RM, Marelli MM, Garattini E, Motta M. Antiproliferative effects of luteinizing hormonereleasing hormone (LHRH) agonists on human androgenindependent prostate cancer cell line DU 145: evidence for an autocrine-inhibitory LHRH loop. Cancer Res. 1994;54(15):40915.

23. Halmos G, Arencibia JM, Schally AV, Davis R, Bostwick DG. High incidence of receptors for luteinizing hormone-releasing hormone (LHRH) and LHRH receptor gene expression in human prostate cancers. J Urol. 2000;163(2):623-9.

24. Pappa EV, Zompra AA, Spyranti Z, Diamantopoulou Z, Pairas $\mathrm{G}$, Lamari FN, et al. Enzymatic stability, solution structure, and antiproliferative effect on prostate cancer cells of leuprolide and new gonadotropin-releasing hormone peptide analogs. Pept Sci. 2011;96(3):260-72.

25. Dondi D, Festuccia C, Piccolella M, Bologna M, Motta M. GnRH agonists and antagonists decrease the metastatic progression of human prostate cancer cell lines by inhibiting the plasminogen activator system. Oncol Rep. 2006;15(2):393-400.

26. Millar RP, Pawson AJ, Morgan K, Rissman EF, Lu Z-L. Diversity of actions of GnRHs mediated by ligand-induced selective signaling. Front Neuroendocrinol. 2008;29(1):17-35.

27. Naor Z, Clayton RN, Catt KJ. Characterization of gonadotropinreleasing hormone receptors in cultured rat pituitary cells. Endocrinology. 1980;107(4):1144-52.

28. Naor Z, Atlas D, Clayton R, Forman D, Amsterdam A, Catt K. Interaction of fluorescent gonadotropin-releasing hormone with receptors in cultured pituitary cells. J Biol Chem. 1981;256(6):3049-52.

29. Smith MA, Perrin MH, Vale WW. Desensitization of cultured pituitary cells to gonadotropin-releasing hormone: evidence for a post-receptor mechanism. Mol Cell Endocrinol. 1983;30(1):8596.

30. Kéri G, Nikolics K, Teplán I, Molnár J. Desensitization of luteinizing hormone release in cultured pituitary cells by gonadotropin-releasing hormone. Mol Cell Endocrinol. 1983;30(1):109-20.

31. Moradi SV, Mansfeld FM, Toth I. Synthesis and in vitro evaluation of glycosyl derivatives of luteinizing hormonereleasing hormone (LHRH). Bioorg Med Chem. 2013;21(14):4259-65.

32. Gao LB, Wang JZ, Yao TW, Zeng S. Study on the metabolic mechanism of chiral inversion of S-Mandelic acid in vitro. Chirality. 2012;24(1):86.

33. Yao J-F, Zhou N, Lv Y-J, Zhang R, Liu K-L, Xue M. Metabolic stability of long-acting luteinizing hormone-releasing hormone antagonists. Amino Acids. 2012;43(4):1557-66.

34. Tomar P, Jain N, Agarwal G, Dixit V. Goserelin loaded nanoparticles inhibit growth and induce apoptosis in human prostate cancer cell lines. Drug Deliv Transl Res. 2012;2(4):26571.

35. Pelletier JC, Chengalvala M, Cottom J, Feingold I, Garrick L, Green D, et al. 2-Phenyl-4-piperazinylbenzimidazoles: orally active inhibitors of the gonadotropin releasing hormone (GnRH) receptor. Bioorg Med Chem. 2008;16(13):6617-40.

36. Moreau J-P, Delavault P, Blumberg J. Luteinizing hormonereleasing hormone agonists in the treatment of prostate cancer: a review of their discovery, development, and place in therapy. Clin Ther. 2006;28(10):1485-508.
37. Padula AM. GnRH analogs-agonists and antagonists. Anim Reprod Sci. 2005;88(1-2):115-26.

38. Ferruzza S, Rossi C, Scarino ML, Sambuy Y. A protocol for in situ enzyme assays to assess the differentiation of human intestinal Caco-2 cells. Toxicol In Vitro. 2012;26(8):1247-51.

39. Katsila T, Balafas E, Liapakis G, Limonta P, Montagnani Marelli M, Gkountelias K, et al. Evaluation of a stable gonadotropinreleasing hormone analog in mice for the treatment of endocrine disorders and prostate cancer. J Pharmacol Exp Ther. 2011;336(3):613-23.

40. Katsila T, Siskos AP, Tamvakopoulos C. Peptide and protein drugs: the study of their metabolism and catabolism by mass spectrometry. Mass Spectrom Rev. 2012;31(1):110-33.

41. Koch Y, Elkabes S, Fridkin M. Degradation of luteinizing hormone-releasing hormone (LHRH) by pituitary plasma membrane and by pituitary cells in culture. Neuroendocrine Molecular Biology: Springer; 1986. pp. 309-23.

42. Gao C-Q, Fraeyman N, Eertmans F, Dhooge W, Kaufman J-M. Further evaluation of the biological activity of the unique gonadotropin-releasing hormone peptide in the guinea pig brain. Neurosci Lett. 2011;487(2):246-9.

43. Carone F, Stetler-Stevenson M, May V, LaBarbera A, Flouret G. Differences between in vitro and in vivo degradation of LHRH by rat brain and other organs. Am J Physiol Endocrinol Metab. 1987;253(3):E317-21.

44. Walters K, Wegorzewska IN, Chin YP, Parikh MG, Wu T. Luteinizing hormone-releasing hormone I (LHRH-I) and its metabolite in peripheral tissues. Exp Biol Med. 2008;233(2):123.

45. Molineaux CJ, Lasdun A, Michaud C, Orlowski M. Endopeptidase-24.15 is the primary enzyme that degrades luteinizing hormone releasing hormone both in vitro and in vivo. $\mathbf{J}$ Neurochem. 1988;51(2):624-33.

46. Yang X, Rojanasakul Y, Wang L, Ma JY, Ma JK. Enzymatic degradation of luteinizing hormone releasing hormone (LHRH)/ [D-Ala6]-LHRH in lung pneumocytes. Pharm Res. 1998;15(9):1480-4.

47. Cummins PM, O'Connor B. Pyroglutamyl peptidase: an overview of the three known enzymatic forms. Biochim Biophys Acta. 1998;1429(1):1-17.

48. Bahk J, Hyun J, Lee B, Kim M, Cho G, Choi W. Expression of gonadotropin-releasing hormone $(\mathrm{GnRH})$ and $\mathrm{GnRH}$ receptor mRNA in prostate cancer cells and effect of GnRH on the proliferation of prostate cancer cells. Urol Res. 1998;26(4):259-64.

49. Limonta P, Marelli MM, Moretti RM. LHRH analogs as anticancer agents: pituitary and extrapituitary sites of action. Expert Opin Investig Drugs. 2001;10(4):709-20.

50. Castellón E, Clementi M, Hitschfeld C, Sánchez C, Benítez D, Sáenz L, et al. Effect of leuprolide and cetrorelix on cell growth, apoptosis, and GnRH receptor expression in primary cell cultures from human prostate carcinoma. Cancer Investig. 2006;24(3):261-8.

51. King JA, Davidson JS, Millar RP. Desensitization to gonadotropin-releasing hormone in perifused chicken anterior pituitary cells*. Endocrinology. 1986;119(4):1510-8.

52. Iida T, Makino T, Seki T, Iizuka R. Mechanism of LH release in cultured rat pituitary cells. Endocrinol Jpn. 1989;36(5):739-46.

53. Levine JE, Duffy MT. Simultaneous measurement of luteinizing hormone (LH)-releasing hormone, LH, and follicle-stimulating hormone release in intact and short-term castrate rats*. Endocrinology. 1988;122(5):2211-21.

54. Drouin J, Fernand L. Selective effect of androgens on LH and FSH release in anterior pituitary cells in culture. Endocrinology. 1976;98(6):1528-34. 